Rights Reserved.

\title{
Extending the Sub-Sea-Floor Biosphere
}

\author{
Erwan G. Roussel ${ }^{1}$, Marie-Anne Cambon Bonavita ${ }^{1}$, Joël Querellou ${ }^{1}$, Barry A. Cragg $^{2}$, \\ Gordon Webster ${ }^{2}$, Daniel Prieur ${ }^{1}$, R. John Parkes ${ }^{2,}$
}

${ }^{1}$ Laboratoire de Microbiologie des Environnements Extrêmes, UMR 6197, Université de Bretagne Occidentale, Ifremer, Centre de Brest, BP70, 29280 Plouzané, France.

${ }^{2}$ School of Earth and Ocean Sciences, Cardiff University, Main Building, Park Place, Cardiff CF10 3YE, UK.

*: Corresponding author : Parkes R. J., email address : $\underline{\text { J.Parkes@earth.cf.ac.uk }}$

\begin{abstract}
:
Sub-sea-floor sediments may contain two-thirds of Earth's total prokaryotic biomass. However, this has its basis in data extrapolation from -500-meter to 4-kilometer depths, whereas the deepest documented prokaryotes are from only 842 meters. Here, we provide evidence for low concentrations of living prokaryotic cells in the deepest (1626 meters below the sea floor), oldest (111 million years old), and potentially hottest $\left(-100^{\circ} \mathrm{C}\right)$ marine sediments investigated. These Newfoundland margin sediments also have DNA sequences related to thermophilic and/or hyperthermophilic Archaea. These form two unique clusters within Pyrococcus and Thermococcus genera, suggesting unknown, uncultured groups are present in deep, hot, marine sediments $\left(-54^{\circ}\right.$ to $\left.100^{\circ} \mathrm{C}\right)$. Sequences of anaerobic methane-oxidizing Archaea were also present, suggesting a deep biosphere partly supported by methane. These findings demonstrate that the sub-sea-floor biosphere extends to at least 1600 meters below the sea floor and probably deeper, given an upper temperature limit for prokaryotic life of at least $113^{\circ} \mathrm{C}$ and increasing thermogenic energy supply with depth.
\end{abstract}


An extensive, global, sub-sea-floor biosphere has recently been documented (1), with the deepest sedimentary prokaryotes so far confirmed at $842 \mathrm{~m}$ depth, $\sim 55^{\circ} \mathrm{C}$, and 3.5 million years (My) old (2). It has been suggested that the sub-sea-floor biosphere may contain two-thirds of Earth's total prokaryotic biomass (3), but this extrapolation requires analysis of prokaryotic populations at greater depths. Here, we provide evidence for living prokaryotic cells in 1626 mbsf (meters below the sea floor) sediments that are $111 \mathrm{My}$ old and at $60^{\circ}$ to $100^{\circ} \mathrm{C}$.

Nine deep sediment samples (4) (860 to $1626 \mathrm{mbsf}$ ) from the Newfoundland Margin [Ocean Drilling Program (ODP) leg 210, site 1276] were analyzed (5). These age from 46 to $111 \mathrm{My}$ and are mainly hemipelagic mudrocks with interbedded gravity-flow deposits, formed during the opening of the northern Atlantic Ocean (4). An igneous sill at $\sim 1613$ mbsf ( 10-m thick) is a trap for gases (methane, Fig. 1) and fluids. On the basis of the local thermal gradient and the measured thermal conductivity (4), the temperature of the deepest sample is calculated to be between $60^{\circ}$ and $100^{\circ} \mathrm{C}$. The upper temperature is close to the highest temperature for prokaryotic growth $\left(\sim 113^{\circ} \mathrm{C}\right)$ and where thermogenic alteration of organic matter can occur. The occurrence of thermogenic reactions and high temperatures $\left(-80^{\circ}\right.$ to $\left.>100^{\circ} \mathrm{C}\right)$ in the deeper part of the core is supported by the presence of high methane concentrations and higher molecular weight hydrocarbons (4).

Intact prokaryotic cells were detected by microscopy in all samples, and many were dividing cells. Depth profiles of cell numbers fluctuate around $1.5 \times 10^{6}$ cells $\mathrm{ml}-1$ (Fig. 1 ), consistent with the general depth distribution of prokaryotic cells from other sub-sea-floor sediments (1). Overall, cell numbers were significantly correlated $(P<0.01)$ with the organic matter hydrogen index $(\mathrm{HI})$, which reflects organic matter reactivity for microorganisms (6) and implies that some of the cells were metabolically active. This is consistent with the presence of dividing cells (Fig. 1) and the detection of live cells using Live/Dead (Molecular Probes Incorporated, Eugene, OR) staining ( $60 \%$ viable cells). Percentages of dividing cells of the total count are in the range of previous results (0 to 4.8\%) (1), except for higher values in the deepest sample (1626 mbsf, 11.8\%). This increase in the proportion of dividing cells is probably related to the dramatic increase in concentrations of methane and higher hydrocarbons together with the generally elevated organic carbon concentrations, both providing potential energy sources (Fig. 1) (4).

Successful archaeal 165 ribosomal RNA (rRNA) gene amplification also strongly suggests that the cells are from living prokaryotes because preservation of extracellular DNA in 46 to $111 \mathrm{My}$ old, hot $\left(60^{\circ}\right.$ to $\left.100^{\circ} \mathrm{C}\right)$ sediments is unlikely. In addition, some detected sequences are related to thermophiles and/or hyperthermophiles, which matches in situ temperatures. The resulting clone libraries show a low diversity of Archaea (Fig. 1), with thermophilic Pyrococcus dominating the 958-m depth, and then, as soon as methane increases above background concentrations, potential anaerobic methane-oxidizing (ANME) sequences became dominant (fig. S1). Surprisingly, there were no ANME sequences in the deepest sample (1626 mbsf) despite the highest methane concentrations; however, at $60^{\circ}$ to $100^{\circ} \mathrm{C}$ this may be above the upper temperature limit for ANME prokaryotes (7). In addition, the Pyrococcus and Thermococcus sequences (fig. S1) in the deepest sample may belong to high-temperature Archaea that are able to use the thermogenic higher hydrocarbons that accumulate below the sill.

These data provide direct evidence that significant prokaryotic populations are present in marine sediments at depths greater than a kilometer and as old as $111 \mathrm{My}$. This study also suggest that Archaea capable of anaerobic oxidation of methane and novel members of the high-temperature Thermococcales (Pyrococcus and Thermococcus) can dominate deep and hot sediments where there are thermogenic energy sources.

\section{References}

1. R. J. Parkes et al., Nature 371, 410 (1994).

2. P. Wellsbury, I. Mather, R. J. Parkes, FEMS Microbiol. Ecol. 42, 59 (2002). 
3. W. B. Whitman, D. C. Coleman, W. J. Wiebe, Proc. Natl. Acad. Sci. U.S.A. 95, 6578 (1998).

4. B. E. Tucholke et al., Drilling the Newfoundland Half of the Newfoundland-Iberia Transect: The First Conjugate Margin Drilling in a Nonvolcanic Rift, vol. 210 of Proceedings of the Ocean Drilling Program, Initial Reports (Ocean Drilling Program, Texas A\&M University, College Station, TX, 2004).

5. Materials and methods are available on Science Online.

6. R. J. Parkes et al., Org. Geochem. 38, 845 (2007).

7. J. Kallmeyer, A. Boetius, Appl. Environ. Microbiol. 70, 1231 (2004).

8. We thank members of the Leg 210 cruise, especially J. C. Sibuet, for obtaining samples and K. E. Louden for helpful discussions and providing the thermal gradient data. This study used data provided by the ODP (www-odp.tamu.edu) and was partly funded from Natural Environment Research Council, UK. GenBank accession numbers are AM418589 to AM418604.

\section{Figures}

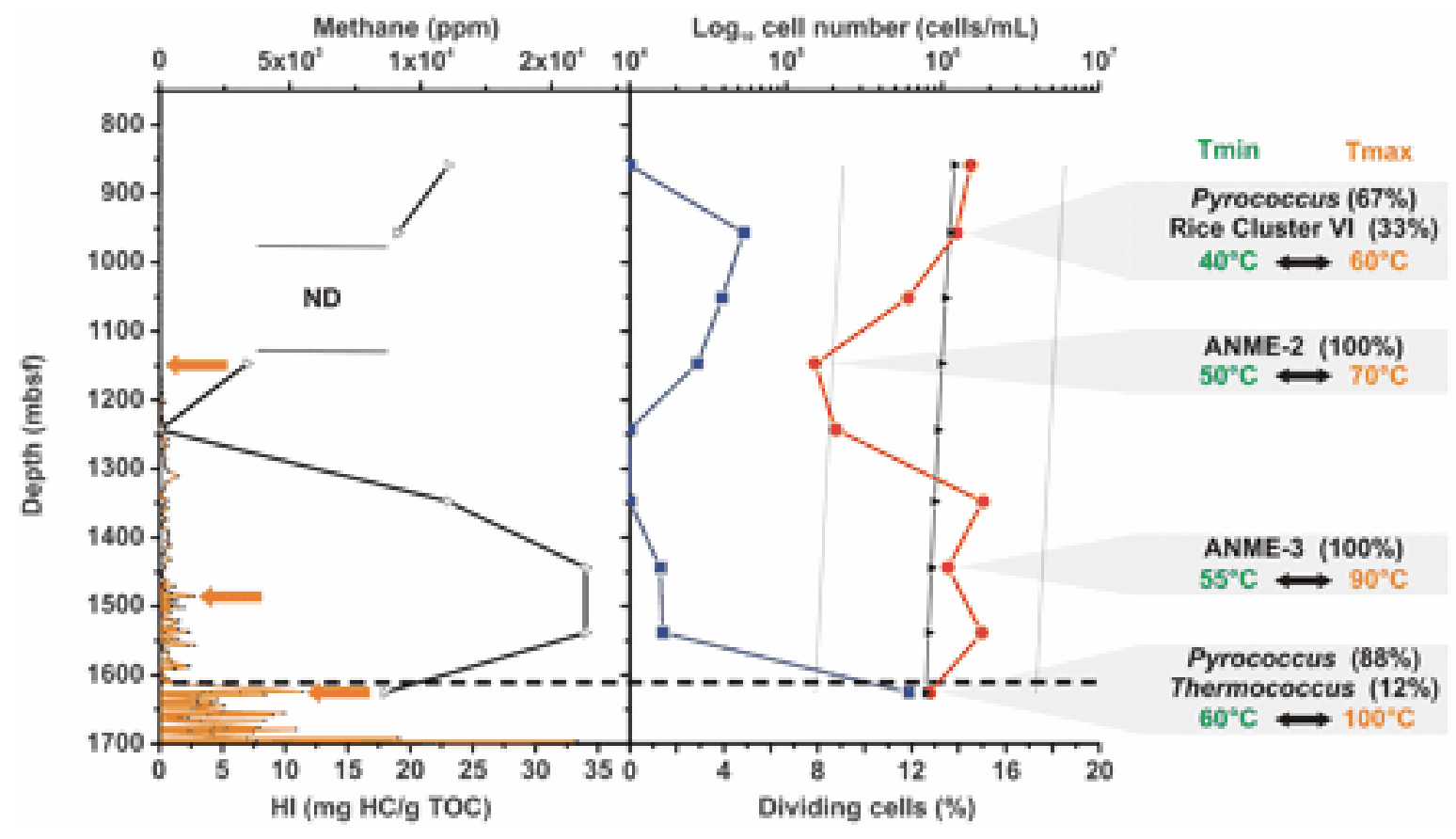

Fig. 1. Depth profiles of methane (black dots with orange line), prokaryotic cells (red circles), and $\%$ dividing cells (blue squares) determined by acridine orange staining. Regression equation ( 1 ) for prokaryotic cells in marine sediments (solid triangles), prediction limits (...). Orange arrows show local increases in methane. $\mathrm{HI}$ (open triangles) measured as mg of hydrocarbon (HC) per $\mathrm{g}$ of total organic carbon (TOC). ND, not determined. Dominant archaeal 16S rRNA gene sequences and in situ temperature range are on the right at the depths obtained. The diabase sill is shown as a bold horizontal dashed line. 